\title{
PERSEPSI KONSUMEN TERHADAP MAKANAN ORGANIK DI SURABAYA
}

\author{
Sienny Thio \\ Program Manajemen Perhotelan, Fakultas Ekonomi, Univeristas Kristen Petra \\ Email: sienny@petra.ac.id
}

Ninna Yuanita Sari Harianto, Ricky Ferdinand Sosiawan

Alumnus Program Manajemen Perhotelan, Fakultas Ekonomi, Universitas Kristen Petra

\begin{abstract}
Abstrak: Penelitian ini dilakukan untuk mengetahui persepsi masyarakat Surabaya terhadap makanan organik. Penelitian ini merupakan penelitian kuantitatif deskriptif dengan 400 responden yang menggunakan teknik judgemental sampling. Persepsi masyarakat terhadap makanan organik dilihat dari persepsi terhadap kesehatan, kualitas, harga, ramah lingkungan, dan food safety. Berdasarkan hasil penelitian dapat disimpulkan bahwa masyarakat Surabaya mempunyai persepsi yang tinggi bahwa makanan organik baik untuk kesehatan yaitu bisa menjaga dan meningkatkan daya tahan tubuh serta mempunyai kandungan nutrisi yang lebih banyak.
\end{abstract}

Kata kunci: persepsi, makanan organik

\begin{abstract}
The aim of this paper is to examine consumers' perception in Surabaya toward organic food. This paper used quantitative descriptive method with 400 respondents using judgemental sampling techinique. Consumers' perception toward organic food is reffered to the perception toward health, quality, price, friendly environment, and also food safety. The findings show that consumers in Surabaya have the highest perception that organic food is good for health because it can keep and increase body immune and also have higher nutrition.
\end{abstract}

Keywords: perception, organic food

Saat ini tren hidup sehat mulai muncul kembali di kalangan sebagian masyarakat. Di Indonesia salah satu dari sekian usaha untuk kembali hidup sehat juga telah dilakukan termasuk dengan memperkenalkan makanan organik. Secara umum makanan organik merupakan makanan yang mempunyai standar kesehatan yang direkomendasikan (Ririn, 2008, November).

Dalam beberapa dekade terakhir telah terjadi peningkatan dalam produksi dan konsumsi makanan yang diproduksi secara organik. Pertanian organik telah diterapkan hampir di sebagian besar negara di dunia. Di seluruh dunia, total area yang digunakan untuk pertanian organik telah tercatat lebih dari 24 juta hektar. Adapun lahan pertanian organik terluas berada di Australia (10,5 juta ha), Argentina (3,2 juta ha), dan Italia (1,2 juta ha). Sementara di wilayah Asia, negara dengan lahan pertanian organik terluas adalah India dan China. (Pranasari, 2004, November).

Dalam hubungannya dengan pertumbuhan permintaan yang potensial, beberapa penelitian telah mengidentifikasi motivasi konsumen dalam membeli makanan organik dan secara umum telah mem- perlihatkan gambaran yang positif terhadap kuatnya permintaan. Menurut Chinnici et al (2002), telah terjadi peningkatan permintaan konsumen untuk produk-produk pertanian yang dihasilkan dengan proses yang ramah terhadap lingkungan, khususnya yang dihasilkan secara organik. Sedangkan menurut Firth et al (2004), walaupun permintaan pasar akan makanan organik masih terbilang kecil, terdapat tanda-tanda bahwa pasar peminat makanan organik semakin dewasa dan berkembang dibandingkan beberapa tahun sebelumnya yang berada dibawah 10 persen.

Konsumen yang membeli makanan organik telah dikelompokkan dalam empat grup (Davis, Titterington and Cochrane, 1995), yaitu greens; konsumen yang memiliki perhatian terhadap lingkungan, food phobic; konsumen yang memiliki perhatian terhadap bahaya kandungan kimia dalam makanan, humanists; konsumen yang memiliki pengetahuan dan kemampuan dalam bidang pertanian dan hedonists; konsumen yang percaya bahwa produk yang lebih mahal pasti lebih baik dan memiliki rasa yang lebih baik. 
Pemerintah Indonesia telah mencanangkan program Go Organic 2010 untuk mempercepat terwujudnya pembangunan agribisnis berwawasan lingkungan (ecoagribusiness). Program ini berorientasi pada pasar yakni berusaha memenuhi keinginan pasar, dimulai dari bawah ke atas. Salah satu kegiatannya adalah memasyarakatkan pertanian organik kepada konsumen, petani, pelaku pasar serta masyarakat luas (Widiastuti, 2004).

Sementara itu pertumbuhan pasar makanan organik di Indonesia terlihat dengan meningkatnya jumlah petani organik, outlet-outlet supermarket dan rumah makan yang menjual produk makanan organik (Sugeng, 2007, September). Di Surabaya sebagian masyarakat bahkan rela mengeluarkan dana lebih besar demi mendapatkan buah atau sayur organik, walaupun makanan organik di tanah air relatif lebih mahal dibandingkan makanan konvensional.

Menurut Sugeng (2007), bahan pangan organik memang berbeda dengan bahan pangan konvensional. Selain lezat cita rasanya, bahan pangan organik lebih menyehatkan dan aman dikonsumsi. Hampir tidak ada pencemaran bahan kimia yang dapat membentuk radikal bebas ditemukan dalam bahan pangan organik. Bahan pangan organik merupakan bahan pangan yang diproduksi secara sedikit atau bebas sama sekali dari unsur kimia berupa pupuk, pestisida, hormon, dan obat-obatan. Bahan pangan organik hanya menggunakan bibit lokal dan pupuk dari alam seperti kotoran hewan atau kompos. Selain itu, bahan pangan organik tidak boleh mengandung bibit yang dihasilkan dari rekayasa genetika dan tidak memanfaatkan teknologi radiasi untuk mengawetkan produknya. Jadi, semua proses produksi dilakukan secara alamiah, mulai aspek budidaya hingga cara pengolahan (Ririn, 2008).

Produk organik memiliki lebih banyak vitamin, mineral, dan enzyme yang baik bagi kesehatan tubuh, juga memiliki rasa yang lezat dan merupakan jalan yang sangat praktis untuk menghindari makanan yang mengandung rekayasa genetik dan zat-zat kimia lain yang tidak baik untuk kesehatan tubuh. Selain itu, dengan mengkonsumsi produk organik secara berkala dapat membantu mengurangi resiko terkena penyakit kronis, seperti kanker, jantung, hipertensi, diabetes, kolesterol, dan lain-lain. Mengkonsumsi makanan organik merupakan langkah awal untuk memulai hidup sehat (Steven, 2007, Maret).

Terdapat beberapa atribut yang dipertimbangkan konsumen dalam membandingkan antara makanan organik dengan makanan konvensional. Pada umumnya konsumen menilai kualitas suatu produk dari tampilannya (Beharrell \& Macfie, 1991), namun hal ini nampaknya bukan merupakan hal yang penting bagi konsumen yang memiliki minat yang tinggi terhadap produk organik (Lin et al., 1986). Rasa, kesegaran, daya tahan (usia) produk (Mahesh et al., 1997; Wandel \& Bugge, 1996), harga (Fotopoulos \&Krystallis, 2003), dampak terhadap lingkungan dan makhluk hidup (Lea \& Worsley, 2005; Goldman \& Clancy, 1991), kandungan zat kimia (Swanson \& Lewis, 1993), dan kesehatan (Fricke \& Von Alvensleben, 1997; Wandel \& Bugge, 1996, Chinnici et al., 2002, Harper \& Makatouni, 2002) dinilai merupakan faktor yang dipertimbangkan konsumen dalam keputusan pembelian (dalam Bonti \& Yiridoe, 2006).

Bagaimanapun juga terdapat persepsi yang berbeda-beda mengenai faktor yang dipertimbangkan dalam keputusan pembelian yang dilakukan oleh konsumen. Sebagai contoh, beberapa hasil penelitian menunjukkan bahwa konsumen mempersepsikan tidak adanya perbedaan rasa antara makanan organik dengan makanan konvensional (Jolly \& Norris, 1991; Sparling et al., 1992), sedangkan hasil penelitian yang lain menunjukkan bahwa makanan organik memiliki rasa yang lebih baik dibandingkan makanan konvensional (Estes et al., 1994; The Parker, 1996).

Dalam penelitian lain (Chinnici et al, 2002; Harper\&Makatouni, 2002; O'Donovan and McCarthy, 2002; Hill and Lynchechaun, 2002; Hutchins\&Greenhalgl, 1995; Berrahel\&MacFie, 1991; Pearson, 2001), menunjukkan bahwa alasan konsumen dalam membeli makanan organik adalah karena keyakinan konsumen bahwa makanan organik lebih sehat dibandingkan makanan organik (dalam Radman, 2005). Perbedaan persepsi ini berdasarkan pada tingkat pengetahuan dan kesadaran konsumen (Jolly et al., 1989; Ekelund, 1990; Hutchins \&Greenhalgh, 1997; Cunningham, 2002), kebiasaan ( habit) atau pola belanja konsumen (Magnusson et al., 2001) dan faktor keberadaan atau eksistensi makanan organik dan konvensional di masyarakat (Sparling et al., 1992).

Penelitian ini dilakukan untuk mengetahui bagaimana persepsi masyarakat Surabaya terhadap makanan organik mengingat terdapat persepsi yang berbeda-beda mengenai faktor yang dipertimbangkan konsumen dalam membeli makanan organik.

\section{TEORI PENUNJANG}

\section{Pengertian Makanan Organik}

National Organic Standards Boards of the U.S. Department of Agriculture (USDA) menetapkan standar nasional untuk istilah "organik". Makanan organik, didefinisikan sebagai makanan atau minuman 
yang diolah atau dihasilkan secara alami melalui standar proses produksi, yang dihasilkan tanpa menggunakan pupuk endapan, pupuk sintetis, pestisida, hormon sintetis dan bahan tambahan lainnya (penambah warna, bau, rasa).

Steven (2007) mengatakan bahwa bahan pangan organik merupakan bahan pangan yang diproduksi secara sedikit atau bebas sama sekali dari unsur kimia berupa pupuk, pestisida, hormon, dan obat-obatan. Bahan pangan organik hanya menggunakan bibit lokal dan pupuk dari alam seperti kotoran hewan atau kompos. Selain itu, bahan pangan organik tidak mengandung bibit yang berasal dari rekayasa genetika (Genetically Modified Organism) dan tidak memanfaatkan teknologi radiasi untuk mengawetkan produknya. Jadi, semua proses produksi dilakukan secara alamiah, mulai aspek budidaya hingga cara pengolahan.

Organik adalah makanan yang dikembangkan dengan metode khusus. Ada sayur organik, buah organik, bahkan daging organik. Yang dimaksud dengan tumbuhan organik (sayur dan buah) adalah tumbuhan yang dikembangkan diatas tanah yang bersih dari unsur-unsur kimiawi dan tidak mengandung pestisida. Tanah tersebut harus dinyatakan bebas kimiawi selama 5 tahun sebelum digunakan sebagai lahan untuk tumbuhan organik. Demikian pula dengan daging organik (seperti ayam dan sapi), harus berasal dari ayam atau sapi yang tidak pernah disuntik hormon pertumbuhan tertentu. Dan para ternak inipun hanya diperbolehkan mengkonsumsi makanan alami (cacing, biji-bijian, dan rumput) dan air yang bebas dari pestisida. (Steven, 2007, Maret).

\section{Makanan Organik Dibandingkan dengan Makanan Konvensional}

Menurut Wirjatmadi (2008), bahan pangan organik memang berbeda dengan bahan pangan konvensional. Selain lezat cita rasanya, bahan pangan organik lebih menyehatkan dan aman dikonsumsi. Hampir tidak ada pencemaran bahan kimia yang dapat membentuk radikal bebas ditemukan dalam bahan pangan organik.

Hasil dari beberapa penelitian sebelumnya menunjukkan bahwa konsumen memiliki sikap yang positif terhadap makanan organik dimana salah satu alasan utamanya adalah bahwa makanan organik dianggap lebih sehat dibandingkan dengan makanan konvensional (Chinnici et al., 2002; Harper \& Makatouni, 2002).

\section{Atribut-Atribut Makanan Organik}

Meskipun atribut dalam makanan organik sulit untuk diidentifikasi dengan melihat secara langsung, kebanyakan konsumen membeli produk organik dikarenakan oleh adanya persepsi terhadap produk makanan organik, dimana makanan organik memiliki atribut yang unik dibandingkan dengan produk konvensional lainnya (Vindigni et al, 2002).

Berdasarkan penelitian Magnusson et al. (2001), mempelajari bahwa kriteria terpenting pada makanan adalah rasa, kesehatan, daya tahan, dan kualitas dalam produk. Survei yang diadakan di European Community, Wandel \& Bugge's (1997) menunjukkan rasa, kesegaran, tampilan dan nilai nutrisi sangat penting dalam memilih sayuran dan buah-buahan. Verbeke (2001) mendemonstrasikan bahwa lima atribut terpenting untuk fresh meat adalah kesegaran, kualitas, rasa, kesehatan dan bebas hormon.

Menurut Schifferstein \& Oude-Ophuis (1997) kualitas makanan, kandungan zat kimia, dampak bagi lingkungan, dan kualitas rasa yang lebih baik adalah faktor terpenting yang mempengaruhi permintaan terhadap makanan organik. Sedangkan Wolf (2002), mengatakan atribut makanan organik yang sangat diinginkan konsumen adalah segar, berkualitas tinggi, harga yang terjangkau, sehat, bergizi tinggi, dan bebas pestisida.

Berdasarkan beberapa hasil penelitian yang dilakukan Magnuson et al., 2001; Wandel \& Bugge's, 1997; Verbeke, 2001; Schifferstein \& Oude-Ophuis, 1997, dan Wolf, 2002. Maka penulis menggunakan atribut-atribut tersebut untuk melihat persepsi dan minat beli konsumen di Surabaya terhadap makanan organik, yaitu sebagai berikut:

1. Kesehatan

Hippocrates, pemikir ilmu kesehatan modern, mengungkapkan, "biarkan makanan menjadi obat Anda dan biarkan obat menjadi makanan Anda". Pemikiran Hippocrates tesebut sekarang digali ulang sebagai landasan bagaimana seharusnya dalam memilih makanan (Siswono, 2003). Produk organik memiliki lebih banyak vitamin, mineral, dan enzim yang baik bagi kesehatan tubuh, juga memiliki rasa yang lezat dan merupakan jalan yang sangat praktis untuk menghindari makanan yang mengandung rekayasa genetik dan zat-zat kimia lain yang tidak baik untuk kesehatan tubuh. Selain itu, dengan mengkonsumsi produk organik secara berkala dapat membantu mengurangi resiko terkena penyakit kronis, seperti kanker, jantung, hipertensi, diabetes, kolesterol, dan lain-lain ("Why Healthy Lunch", 2008, Mei). Ekelund (1990) melihat motivasi untuk membeli makanan 
organik adalah alasan kesehatan dan tidak adanya kontaminasi. Pembeli makanan organik lebih sadar akan kesehatan, dan tidak memiliki keyakinan pada makanan konvensional (Fricke \& Von Alvensleben, 1997). Penelitian serupa oleh Wandel \& Bugge (1995) menunjukkan motivasi semua pembeli dalam membeli makanan organik adalah karena alasan kesehatan.

2. Kualitas

Kyriakopoulos et al. (1997) menunjukkan bahwa kualitas makanan lebih penting dibandingkan harga. Jurnal of Applied Nutrition (1993) sangat jelas memperlihatkan bahwa makanan organik lebih bernutrisi dibandingkan dengan makanan konvensional. Sayuran organik lebih disenangi karena kesegaran, rasa dan persepsi akan mutu nutrisi (Mahesh et al., 1997). Sedangkan menurut Wandel \& Bugge (1996) menunjukkan mayoritas responden memberi peringkat pertama pada kesegaran, kemudian diikuti oleh rasa dan kandungan nutrisinya.

3. Harga

Produk organik pada umumnya memiliki harga sekitar $10-40 \%$ lebih mahal dibandingkan dengan produk konvensional (Winter \& Davis, 2006). Saat ini harga produk organik masih tergolong tinggi di Indonesia, karena jumlah produk yang tersedia masih sedikit ("Peluang dan Tantangan Bagi Petani Kecil”, November, 2004). Fotopoulos \& Krystallis (2003) menemukan perilaku positif bahwa konsumen makanan organik bersedia membayar harga yang lebih mahal, ini menunjukkan bahwa pembeli makanan organik percaya bahwa makanan organik memiliki nilai manfaat yang lebih meskipun harganya lebih mahal. Harga makanan organik cenderung lebih tinggi dibandingkan dengan makanan konvensional. Food and Agriculture Organization (FAO) manyatakan bahwa produk makanan organik umumnya lebih mahal dibandingkan dengan produk konvensional (Food And Agriculture Organization of The United Nation, 2003).

4. Ramah lingkungan

Pertanian organik pada prinsipnya adalah budidaya pertanian yang dikembangkan tanpa bergantung pada pasokan pupuk ataupun obat-obatan kimia sintetis guna memenuhi kebutuhan nutrisi tanaman. Pertanian organik dalam budidayanya menjadikan pupuk alami (pupuk yang berbahan baku kotoran hewan seperti Domba, Kambing, Sapi, Kelinci bisa juga Kelelawar kemudian dapat pula limbah dedaunan) sebagai pasokan guna memenuhi kebutuhan nutrisi tanaman maupun ketika mengatasi serangan hama dan penyakit pada tanaman. ("Pertanian Organik Dan Revitalisasi Pertanian", 2005, Maret). IFOAM (International Federation of Organic Agriculture Movement) menjelaskan bahwa pertanian organik merupakan suatu pendekatan sistem yang utuh berdasarkan satu perangkat proses yang menghasilkan ekosistem yang berkelanjutan, pangan yang aman, gizi yang baik, kesejahteraan hewan, dan keadilan sosial. Dengan demikian, pertanian organik lebih dari sekedar sistem produksi yang memasukkan atau mengeluarkan input tertentu, namun juga merupakan satu filosofi dengan tujuan mengoptimalkan kesehatan dan produktivitas dari komunitas yang saling berketergantungan dari kehidupan tanah, tanaman, hewan, dan manusia ("Pertanian Organik Dan Revitalisasi Pertanian", 2005, Maret).

\section{Food Safety}

Swanson dan Lewis (1993) menunjukkan bahwa konsumen makanan organik lebih perhatian terhadap residu pestisida, zat-zat kimia tambahan, dan zat pengawet dibandingkan dengan non konsumen makanan organik. Berdasarkan survei terbaru, $70 \%$ konsumen menyatakan bahwa membeli makanan organik untuk menghindari pestisida (Whole Food Market, 2005). Penelitian yang lain menjelaskan persepsi bahwa makanan yang tumbuh secara organik memiliki kandungan bahan kimia dan kontaminasi mikroba yang lebih sedikit dibandingkan dengan makanan yang diproduksi secara konvensional. Wilkins \& Hillers (1994) memperlihatkan bahwa perhatian terhadap kandungan pestisida adalah faktor yang paling mempengaruhi preferensi terhadap makanan organik. Goldman \& Clancy (1991) menemukan bahwa konsumen makanan organik yang berada di negara bagian New York kebanyakan memperhatikan adanya residu pestisida dan efek dari pestisida bagi kesehatan. Alasan utama konsumen untuk membeli makanan organik adalah food safety, perlindungan terhadap lingkungan dan sebagai tindakan nyata untuk mendukung pertanian organik.

\section{METODE PENELITIAN}

\section{Jenis Penelitian, Populasi dan Sampel}

Jenis penelitian yang digunakan dalam penelitian ini adalah penelitian kuantitatif deskriptif. Adapun populasi dalam penelitian ini adalah masyarakat Surabaya yang berbelanja di supermarket yang menjual produk makanan organik. Dalam penelitian 
ini pengambilan sampel dilakukan dengan teknik judgemental sampling. Sampel dalam penelitian ini adalah masyarakat Surabaya yang berbelanja di supermarket yang menjual produk makanan organik (Healthy Choice, Sinar Jemur Andayani, Sinar Bintoro dan Hokky Buah Ruko Graha Family) dan berusia diatas 21 tahun keatas.

Adapun sampel penelitian ini adalah 400 sampel. Pembagian jumlah kuesioner untuk setiap lokasi penyebaran adalah sebanyak 150 kuesioner disebarkan di Sinar Bintoro, 120 kuesioner di Sinar Jemursari, 80 kuesioner di Hokky Buah, dan 50 kuesioner di Healthy Choice.

\section{Jenis dan Sumber data}

Dalam penelitian ini jenis data yang dikumpulkan, yaitu: (1) Data Primer, yaitu berupa kuesioner yang disebarkan kepada orang-orang yang berbelanja di supermarket yang menjual makanan organik yang sesuai dengan sampel yang telah ditentukan; (2) Data sekunder, yaitu berupa data atau informasi yang diperoleh melalui studi kepustakaan, teori, literatur, jurnal atau catatan yang berhubungan dengan makanan organik.

\section{Definisi Operasional Variabel}

Dalam penelitian ini, variabel yang akan digunakan adalah sebagai berikut:

a. Persepsi tentang Kesehatan $\left(\mathrm{X}_{1}\right)$ merupakan suatu proses dalam memilih, mengorganisasikan dan menginterpretasikan makanan organik dilihat dari atribut kesehatan. Pengukuran variabel didasarkan pada indikator persepsi tentang kesehatan, yaitu:

1. Menjaga daya tahan tubuh, dalam arti mengurangi resiko terkena penyakit kronis

2. Memiliki kandungan nutrisi yang lebih banyak dibandingkan dengan makanan konvensional

b. Persepsi tentang Kualitas $\left(\mathrm{X}_{2}\right)$ merupakan suatu proses dalam memilih, mengorganisasikan dan menginterpretasikan makanan organik dilihat dari atribut kualitas. Pengukuran variabel didasarkan pada indikator persepsi tentang kesehatan, yaitu:

1. Makanan organik memiliki rasa yang lebih lezat dibandingkan makanan konvensional

2. Makanan organik lebih segar dibandingkan dengan makanan konvensional

c. Persepsi tentang Harga $\left(\mathrm{X}_{3}\right)$ merupakan suatu proses dalam memilih, mengorganisasikan dan menginterpretasikan makanan organik dilihat dari atribut harga. Pengukuran variabel didasarkan pada indikator persepsi tentang harga, yaitu:
1. Kesediaan konsumen membayar harga yang lebih mahal untuk membeli makanan organik

2. Harga yang dibayar sesuai dengan kualitas yang diterima

d. Persepsi tentang Ramah Lingkungan $\left(\mathrm{X}_{4}\right)$ merupakan suatu proses dalam memilih, mengorganisasikan dan menginterpretasikan makanan organik dilihat dari atribut ramah lingkungan. Pengukuran variabel didasarkan pada indikator persepsi tentang ramah lingkungan, yaitu:

1. Budi daya makanan organik baik bagi kelestarian lingkungan

2. Budi daya organik lebih aman bagi kelangsungan hidup hewan dan tanaman

e. Persepsi tentang Food Safety $\left(\mathrm{X}_{5}\right)$ merupakan suatu proses dalam memilih, mengorganisasikan dan menginterpretasikan makanan organik dilihat dari atribut food safety. Pengukuran variabel didasarkan pada indikator persepsi tentang food safety, yaitu:

1. Makanan organik bebas dari kandungan zat kimia

2. Makanan organik tidak menggunakan rekayasa genetika

f. Minat Beli merupakan keinginan konsumen untuk melakukan pembelian makanan organik. Pengukuran variabel didasarkan pada konsumen yang pernah membeli makanan organik dan berminat untuk melakukan pembelian ulang.

\section{TEKNIK ANALISA DATA}

\section{Statistik Deskriptif}

Dalam penelitian ini penulis melakukan perhitungan frekuensi dan Mean (nilai rata-rata) untuk memberikan gambaran atau deskripsi mengenai persepsi dan minat beli konsumen terhadap makanan organik.

\section{Analisa Top Two Boxes Bottom Two Boxes}

Analisa Top Two Boxes Bottom Two Boxes adalah metode yang menggabungkan presentase jawaban responden dalam skala Likert. Analisa Top Two Boxes Bottom Two Boxes digunakan untuk mengetahui bagaimana perbandingan antara jumlah bottom option (skor 1,2) yaitu skala sangat tidak setuju dan tidak setuju dengan top option (skor 4,5) yaitu skala setuju dan sangat setuju. Selanjutnya Top Two Boxes akan disingkat (TTB), sedangkan Bottom Two Boxes akan disingkat (BTB). 


\section{ANALISIS DAN PEMBAHASAN}

\section{Demografis Responden}

Dari 400 kuesioner yang disebarkan terdapat 20 kuesioner yang dinyatakan error, dikarenakan terdapat butir-butir pernyataan yang tidak terjawab, sehingga jumlah total kuesioner yang terkumpul adalah sebanyak 380 kuesioner. Dari 380 responden penelitian terdapat 220 responden yang menyatakan pernah melakukan pembelian terhadap produk makanan organik dan sebanyak 160 responden yang menyatakan tidak pernah melakukan pembelian terhadap produk makanan organik.

Responden dalam penelitian ini didominasi oleh wanita sebesar $53,9 \%$ dan pria $46,1 \%$ dengan usia antara 31-40 tahun sebesar 30,3\% dan 26-30 tahun sebesar 27,4\%. Responden dalam penelitian ini memiliki penghasilan per bulan Rp. 3.000.000 - Rp. 4.999.999 sebesar 32,6\% dan sebesar 28,2\% memiliki penghasilan antara Rp. 1.000.000 - Rp. 2.999.999. Sedangkan hanya sebagian kecil dari responden yang memiliki penghasilan dibawah Rp. 1.000 .000 sebesar 6,8\% (26 orang). Adapun pekerjaan responden sebagian besar adalah pegawai swasta dan wiraswasta sebesar 64,2\% dan sisanya adalah pelajar/mahasiswa dengan pendidikan terakhir S1 sebesar 56,3\% dan SLTP / SMU sebesar 30,3\%.

Sebagian besar responden dalam penelitian ini pernah melakukan pembelian terhadap produk makanan organik dengan presentase sebesar 57,9\% (220 orang). Sedangkan sisanya sebesar 42,1\% (160 orang) menyatakan bahwa tidak pernah melakukan pembelian terhadap produk makanan organik.

\section{Profil Responden Yang Pernah Membeli Makanan Organik}

Responden yang pernah membeli makanan organik dalam penelitian ini didominasi oleh wanita sebesar $58,6 \%$ dan pria pria sebesar $41,4 \%$ dengan rentang usia 31-40 tahun sebesar 35\%, 21- 25 dan 2630 tahun masing-masing sebesar $22,7 \%$ (50 orang) yang memiliki penghasilan per bulan Rp. 3.000.000 Rp. 4.999.999 sebesar 34,5\% dan sebesar 22,3\% memiliki penghasilan antara Rp. 5.000.000 - Rp. 6.999.999. Sedangkan hanya sebagian kecil dari responden yang memiki penghasilan dibawah $\mathrm{Rp}$. 1.000 .000 sebesar $7,7 \%$ (17 orang) yang sebagian besar memiliki pekerjaan sebagai pegawai swasta dan wiraswasta sebesar $65,9 \%$ dengan tingkat pendidikan terakhir S1 sebesar 60,5\% dan SLTP / SMU sebesar $25,5 \%$.
Responden yang pernah membeli makanan organik dalam penelitian ini memperoleh informasi tentang makanan organik melalui referensi dari orang lain sebesar 50,9\% dan sebesar 32,3\% memperoleh informasi mengenai makanan organik dari media cetak. Kendala terbesar responden yang pernah membeli makanan organik dalam membeli produk makanan organik adalah karena kesulitan mencari jenis produk yang diinginkan sebasar 33,6\%. Dan kendala terbatasnya tempat yang menjual makanan organik yang dialami oleh responden sebesar $31,4 \%$. Sedangkan kendala kurangnya informasi mengenai makanan organik dan harga lebih mahal masingmasing sebesar $17,3 \%$. Frekuensi responden yang pernah membeli makanan organik dalam penelitian ini melakukan pembelian makanan organik dalam sebulan terbesar adalah sebanyak $2-5$ kali yaitu sebesar $42,7 \%$ dan yang melakukan pembelian hanya sekali dalam sebulan sebesar 35,0\%. Responden yang pernah membeli makanan organik dalam penelitian ini membeli makanan organik dengan motivasi makanan organik lebih sehat sebesar $42,7 \%$ dan sebesar $24,1 \%$ memiliki motivasi hanya sekedar mencoba. Sedangkan motivasi responden bahwa makanan organik lebih berkualitas (lezat dan segar) sebesar $15,9 \%$. Sebanyak $58,2 \%$ responden sering membeli makanan organik berjenis sayuran dan buah-buahan sebesar $31,8 \%$. Responden yang pernah membeli makanan organik memiliki toleransi pada tingkat harga makanan organik antara 10\% - 30\% lebih mahal sebesar $37,7 \%$ dan sebesar 35,9\% memiliki toleransi tingkat harga makanan organik antara 30\% - 50\% lebih mahal. Responden yang pernah membeli makanan organik memiliki minat untuk membeli kembali makanan organik sebesar $88,2 \%$ dan tidak memiliki minat beli kembali sebesar 11,8\%.

\section{Profil Responden Yang Tidak Pernah Membeli Makanan Organik}

Responden yang tidak pernah membeli makanan organik didominasi oleh responden pria sebesar $52,5 \%$ dan wanita sebesar $47,5 \%$ dengan rentang usia 26 - 30 tahun sebesar 33,8\% dan 21- 25 tahun sebesar $30,6 \%$ yang berpenghasilan Rp. $1.000 .000-R p$. 2.999 .999 per bulan sebesar 41,9\% dan sebesar 30\% memiliki penghasilan per bulan antara Rp. 3.000.000 - Rp. 4.999.999. Adapun pekerjaan responden sebagai pegawai swasta sebesar 50,6\% dan sebesar $23,8 \%$ sebagai pelajar / mahasiswa dengan pendidikan terakhir adalah S1 sebesar 50,6\% dan SLTP/SMU sebesar 36,9\%. 
Responden yang tidak pernah membeli makanan organik dalam penelitian ini mengetahui makanan organik melalui media cetak sebesar $46,3 \%$ dan sebesar 28,8\% mengetahui makanan organik melalui internet. Diketahui pula bahwa responden yang tidak pernah membeli makanan organik menyatakan kendala utama tidak membeli makanan organik adalah karena harga makanan organik lebih mahal sebesar $40,6 \%$ dan sebesar $29,4 \%$ mempunyai kendala kurangnya informasi mengenai makanan organik.

\section{Deskripsi Persepsi Responden Terhadap Makanan Organik}

Gambaran mengenai persepsi konsumen diperoleh melalui hasil dari responden dalam menjawab pertanyaan kuesioner mengenai 10 (sepuluh) pernyataan tentang persepsi konsumen terhadap makanan organik yang diperoleh, yang menggunakan skala Likert dari skala sangat setuju sampai sangat tidak setuju. Kemudian dicari mean atau rata-rata dari seluruh variabel yang ada untuk menentukan klasifikasi penilaian persepsi responden mengenai pernyataan variabel-variabel penelitian. Pernyataan responden mengenai persepsi tehadap item instrumen pernyataan dibawah ini.

\section{Tabel 1. Nilai Mean Persepsi Responden}

\begin{tabular}{clcc}
\hline Variabel & \multicolumn{1}{c}{ Persepsi } & Mean & SD \\
\hline X1 & Persepsi Terhadap Kesehatan & 4,12 & 0,627 \\
X2 & Persepsi Terhadap Kualitas & 3,81 & 0,609 \\
X3 & Persepsi Terhadap Harga & 3,99 & 0,630 \\
X4 & Persepsi Terhadap Ramah Lingkungan & 4,01 & 0,534 \\
X5 & Persepsi Terhadap Food Safety & 4,09 & 0,637 \\
\hline
\end{tabular}

Tabel 1 menunjukkan bahwa rata-rata persepsi responden terhadap setiap pernyataan tentang makanan organik adalah antara 3,5-4,2 maka dapat dikatakan bahwa responden memiliki persepsi yang cukup baik terhadap pernyataan variabel persepsi yang diteliti. Dari nilai mean yang didapatkan menjelaskan bahwa persepsi responden mengenai makanan organik yang tertinggi adalah persepsi terhadap kesehatan sebesar 4,12 dimana makanan organik dianggap lebih bernutrisi dibandingkan dengan makanan konvensional lainnya dan makanan organik mampu meningkatkan daya tahan tubuh. Sedangkan persepsi untuk kualitas dari makanan organik memiliki persepsi yang paling rendah atau dengan kata lain, responden mengatakan bahwa makanan organik tidak lebih lezat dan lebih segar dibandingkan dengan makanan konvensional.
Tabel 2. Nilai Mean Persepsi untuk Tiap Indikator

\begin{tabular}{|c|c|c|c|}
\hline Persepsi & Indikator & Mean & SD \\
\hline \multirow{2}{*}{ Kesehatan } & $\begin{array}{l}\text { Menjaga dan meningkatkan } \\
\text { daya tahan tubuh }\end{array}$ & 4,16 & 0,648 \\
\hline & $\begin{array}{l}\text { Memiliki kandungan nutrisi } \\
\text { lebih banyak }\end{array}$ & 4,07 & 0,755 \\
\hline \multirow{2}{*}{ Kualitas } & $\begin{array}{l}\text { Memiliki rasa yang lebih } \\
\text { lezat }\end{array}$ & 3,56 & 0,792 \\
\hline & $\begin{array}{l}\text { Memiliki tingkat kesegaran } \\
\text { yang lebih tinggi }\end{array}$ & 4,07 & 0,644 \\
\hline \multirow[b]{2}{*}{ Harga } & $\begin{array}{l}\text { Harga sesuai dengan kualitas } \\
\text { yang diperoleh }\end{array}$ & 3,73 & 0,896 \\
\hline & $\begin{array}{l}\text { Harga lebih mahal } \\
\text { dibandingkan makanan } \\
\text { konvensional }\end{array}$ & 4,25 & 0,636 \\
\hline \multirow{2}{*}{ Ramah Lingkungan } & $\begin{array}{l}\text { Lebih baik bagi kelestarian } \\
\text { lingkungan }\end{array}$ & 4,16 & 0,575 \\
\hline & $\begin{array}{l}\text { Lebih aman bagi } \\
\text { keselamatan hewan }\end{array}$ & 3,86 & 0,671 \\
\hline \multirow[t]{2}{*}{ Food Safety } & $\begin{array}{l}\text { Bebas dari kandungan zat } \\
\text { kimia tambahan }\end{array}$ & 4,09 & 0,659 \\
\hline & Bebas dari rekayasa genetika & 4,09 & 0,721 \\
\hline
\end{tabular}

Berdasarkan tabel 2 dapat dijelaskan bahwa dari nilai mean indikator persepsi responden mengenai makanan organik yang tertinggi adalah indikator persepsi yang menyatakan bahwa harga makanan organik lebih mahal dibandingkan makanan konvensional sebesar 4,25.

Tabel 3. Nilai Mean Persepsi Responden Pernah Membeli dan Tidak Pernah Membeli Makanan Organik

\begin{tabular}{clcc}
\hline Variabel & \multicolumn{1}{c}{ Persepsi } & $\begin{array}{c}\text { Pernah } \\
\text { Membeli }\end{array}$ & $\begin{array}{c}\text { Tidak Pernah } \\
\text { Membeli }\end{array}$ \\
\hline X1 & Persepsi Terhadap & 4,311 & 3,850 \\
& Kesehatan & & \\
X2 & Persepsi Terhadap Kualitas & 4,050 & 3,488 \\
X3 & Persepsi Terhadap Harga & 4,116 & 3,822 \\
X4 & Persepsi Terhadap Ramah & 4,098 & 3,894 \\
& Lingkungan & & \\
X5 & Persepsi Terhadap Food & 4,250 & 3,875 \\
\multicolumn{2}{l}{ Safety } & & \\
\hline
\end{tabular}

Tabel 3 menunjukkan bahwa dari nilai mean yang didapatkan dapat dijelaskan bahwa persepsi tertinggi responden yang pernah membeli makanan organik adalah persepsi terhadap kesehatan sebesar 4,311 dimana makanan organik dianggap lebih bernutrisi dibandingkan dengan makanan konvensional lainnya dan makanan organik mampu meningkatkan daya tahan tubuh. Sedangkan untuk persepsi tertinggi responden yang tidak pernah membeli makanan organik adalah terhadap persepsi terhadap ramah lingkungan sebesar 3,894 dimana budidaya makanan organik dianggap baik bagi kelestarian lingkungan dan lebih aman bagi keselamatan hewan. 
Tabel 4. Nilai Mean Indikator Persepsi Responden Terhadap Makanan Organik

\begin{tabular}{|c|c|c|c|}
\hline Persepsi & Indikator & $\begin{array}{l}\text { Pernah } \\
\text { Beli }\end{array}$ & $\begin{array}{c}\text { Tidak } \\
\text { Pernah } \\
\text { Beli }\end{array}$ \\
\hline \multirow[t]{2}{*}{ Kesehatan } & $\begin{array}{l}\text { Menjaga dan } \\
\text { meningkatkan daya } \\
\text { tahan tubuh }\end{array}$ & 4,34 & 3,92 \\
\hline & $\begin{array}{l}\text { Kandungan nutrisi lebih } \\
\text { banyak }\end{array}$ & 4,29 & 3,78 \\
\hline \multirow[b]{2}{*}{ Kualitas } & Rasa yang lebih lezat & 3,84 & 3,18 \\
\hline & $\begin{array}{l}\text { Tingkat kesegaran lebih } \\
\text { tinggi }\end{array}$ & 4,26 & 3,80 \\
\hline \multirow[b]{2}{*}{ Harga } & $\begin{array}{l}\text { Harga sesuai dengan } \\
\text { kualitas yang diperoleh }\end{array}$ & 3,99 & 3,38 \\
\hline & $\begin{array}{l}\text { Harga lebih mahal } \\
\text { dibandingkan makanan } \\
\text { konvensional }\end{array}$ & 4,24 & 4,26 \\
\hline \multirow{2}{*}{$\begin{array}{l}\text { Ramah } \\
\text { Lingkung } \\
\text { an }\end{array}$} & $\begin{array}{l}\text { Baik bagi kelestarian } \\
\text { lingkungan }\end{array}$ & 4,23 & 4,06 \\
\hline & $\begin{array}{l}\text { Aman bagi } \\
\text { kelangsungan hidup } \\
\text { hewan }\end{array}$ & 3,96 & 3,73 \\
\hline \multirow{2}{*}{$\begin{array}{l}\text { Food } \\
\text { Safety }\end{array}$} & $\begin{array}{l}\text { Bebas dari kandungan } \\
\text { zat kimia }\end{array}$ & 4,25 & 3,88 \\
\hline & $\begin{array}{l}\text { Bebas dari rekayasa } \\
\text { genetika }\end{array}$ & 4,25 & 3,88 \\
\hline
\end{tabular}

Tabel 4 menunjukkan bahwa dari nilai mean indikator persepsi yang didapatkan dapat dijelaskan bahwa indikator persepsi tertinggi responden yang pernah membeli makanan organik adalah indikator persepsi yang menyatakan bahwa makanan organik mampu menjaga dan meningkatkan daya tahan tubuh sebesar 4,34. Sedangkan untuk nilai mean indikator persepsi tertinggi responden yang tidak pernah membeli makanan organik adalah indikator persepsi yang menyatakan bahwa harga makanan organik lebih mahal dibandingkan makanan konvensional sebesar 4,26.

\section{Analisa Top Two Boxes Bottom Two Boxes}

Analisa Top Two Boxes Bottom Two Boxes digunakan untuk mengetahui persepsi responden terhadap makanan organik dilihat dari jawaban teratas, yaitu responden yang menjawab sangat setuju dan setuju untuk tiap indikator. Untuk analisa Top Two Boxes (TTB) diambil dua indikator dengan nilai tertinggi, sedangkan untuk Bottom Two Boxes (BTB) diambil dari dua indikator dengan nilai terendah.

Berdasarkan tabel analisa Top Two Boxes dapat diketahui bahwa responden setuju terhadap pernyataan indikator persepsi yang menyatakan bahwa harga makanan organik lebih mahal dibandingkan harga makanan konvensional dan budidaya makanan organik yang ramah terhadap lingkungan. Selain itu berdasarkan analisa Bottom Two Boxes responden menyatakan tidak setuju terhadap pernyataan indikator persepsi yang menyatakan bahwa harga makanan organik sesuai dengan kualitas dan makanan organik memiliki rasa yang lebih lezat dibandingkan makanan konvensional.

Tabel 5. Analisa Top Two Boxes dan Bottom Two Boxes

\begin{tabular}{llccc}
\hline No & \multicolumn{1}{c}{ Indikator Persepsi } & $\begin{array}{c}\text { TTB } \\
(\%)\end{array}$ & $\begin{array}{c}\text { Netral } \\
(\%)\end{array}$ & $\begin{array}{c}\text { BTB } \\
(\%)\end{array}$ \\
\hline 1 & $\begin{array}{l}\text { Harga Makanan Organik Lebih } \\
\text { Mahal }\end{array}$ & 92,8 & 5,3 & 1,8 \\
\hline 2 & $\begin{array}{l}\text { Makanan Organik Ramah } \\
\text { Lingkungan }\end{array}$ & 91,4 & 8,2 & 0,5 \\
\hline 3 & $\begin{array}{l}\text { Makanan Organik Meningkatkan } \\
\text { Daya Tahan Tubuh }\end{array}$ & 87,4 & 11,8 & 0,8 \\
\hline 4 & $\begin{array}{l}\text { Makanan Organik Bebas Zat Kimia } \\
\text { Tambahan }\end{array}$ & 83,7 & 15,8 & 0,5 \\
\hline 5 & Makanan Organik Lebih Segar & 83,4 & 16,1 & 0,5 \\
\hline 6 & $\begin{array}{l}\text { Makanan Organik Aman Bagi } \\
\text { Keselamatan Hewan }\end{array}$ & 83,4 & 24,7 & 1,8 \\
\hline 7 & $\begin{array}{l}\text { Makanan Organik Bebas Rekayasa } \\
\text { Genetika }\end{array}$ & 82,3 & 16,3 & 1,3 \\
\hline 8 & Makanan Organik Lebih Bernutrisi & 81,3 & 16,3 & 2,3 \\
\hline 9 & $\begin{array}{l}\text { Harga Makanan Organik Sesuai } \\
\text { Kualitas }\end{array}$ & 61,0 & 30,0 & 8,9 \\
\hline 10 & Makanan Organik Lebih Lezat & 53,4 & 38,4 & 8,2 \\
\hline
\end{tabular}

\section{KESIMPULAN DAN SARAN}

\section{Kesimpulan}

1. Konsumen di Surabaya secara umum memiliki persepsi yang cukup baik terhadap produk makanan organik ditinjau dari atribut kesehatan, kualitas, harga, ramah lingkungan, dan food safety. Responden yang pernah membeli makanan organik memiliki tingkat persepsi yang lebih tinggi terhadap kesehatan, dimana makanan organik dianggap lebih bernutrisi dibandingkan dengan makanan konvensional lainnya dan makanan organik dianggap mampu meningkatkan daya tahan tubuh. Sedangkan responden yang tidak pernah membeli makanan organik memiliki persepsi yang lebih tinggi terhadap ramah lingkungan, dimana budidaya makanan organik dianggap baik bagi kelestarian lingkungan dan lebih aman bagi kelangsungan hidup hewan dan tanaman.

2. Responden yang pernah membeli makanan organik diketahui bahwa sebesar $88,2 \%$ responden memiliki minat untuk melakukan pembelian ulang terhadap makanan organik dan sebesar $11,8 \%$ responden menyatakan tidak berminat untuk melakukan pembelian ulang. 
3. Berdasarkan analisa Top Two Boxes dan Bottom Two Boxes responden memiliki persepsi tertinggi terhadap makanan organik adalah harga makanan organik lebih mahal dibandingkan dengan makanan konvensional dan budidaya makanan organik lebih ramah terhadap lingkungan. Sedangkan persepsi terendah responden terhadap makanan organik adalah harga makanan organik dianggap tidak sesuai dengan kualitas dan makanan organik dianggap tidak memiliki rasa yang lebih lezat dibandingkan makanan konvensional.

\section{Saran}

Berdasarkan hasil penelitian diatas, maka disarankan beberapa hal, yaitu:

1. Pemerintah diharapkan untuk lebih memperluas jaringan distribusi produk makanan organik kepada masyarakat, serta berusaha mengoptimalkan lahan-lahan pertanian dan peternakan organik dalam negeri, mengingat harga produk makanan organik impor yang sangat mahal.

2. Promosi bagi para pelaku usaha, dikarenakan masih cukup banyak kalangan masyarakat yang belum sadar tentang keberadaan makanan organik. Melalui promosi masyarakat akan lebih tertarik dan mengerti tentang berbagai manfaat yang terdapat pada produk-produk makanan organik.

3. Edukasi dari para pelaku usaha dan pemerintah kepada masyarakat untuk lebih mengenal makanan organik juga diperlukan, sehingga masyarakat dapat lebih memahami tentang makanan organik dan perbedaan apa yang terdapat pada makanan organik dan makanan konvensional. Edukasi ini dapat dilakukan melalui media cetak, radio, atau seminar.

\section{DAFTAR PUSTAKA}

Band, W.A. (1991). Creating value customer: Designing and implementation a total corporate strategy. Canada: John Willey and sons, Inc.

Beharrel, B. and Macfie, J.H. (1991). Consumers attitudes towards organic foods. British Food Journal, Vol. 93 (2), 25-30

Bonti-Ankomah, S. and Yiridoe, E.K. (2006). Organic and conventional food: A literature review of the economics of consumer perceptions and preferences. Retrieved March 3, 2008, from http:/www.organicagcentre.ca

Chinnici, G. D'Amico, M. and Pecorino, B. (2002). A multivariate statistical analysis on the consumers of organic products. British Food Journal, Vol. 104, 187-199

Davies, A., Titteington, A. and Cochrane, C. (1995). Who buy organic food? A profile of the purchasers of organic food in Northern Ireland. British Food Journal , Vol. 97 (10), 17-23. Retrieved February 20, 2008, from British Food Science (Proquest) database.

Engel, James F. Blackwell, Roger D. \& Miniard, Paul W. (1994). Perilaku Konsumen (6 ${ }^{\text {th }}$ ed.). Jakarta : Binarupa Aksara

Firth, C., Geen, N., Foster, C., Green, M., Haward, R. and Smithson, A. (2004). The UK organic vegetable market. British Food Journal, Vol. $107,606-625$

Fotopoulos, C. and Krystallis, A. (2003). Purchasing motives and profile of the Greek organic consumer: a countrywide survey. British Food Journal, Vol. 104 (9), 730-765

Ghozali, I., (2002). Aplikasi analisis multivariabel dengan program SPSS. ( $2^{\text {nd }}$ ed.). Semarang: Penerbit Universitas Diponegoro

Goldman, B.J. and Clancy, K.C. (1991). A survey of organic produce purchases and related attitudes of food cooperative shoppers. American Journal of Alternative Agriculture, Vol. 6, 8995

Harper, G.C. and Makatouni, A. (2002). Consumer perception of organic food production and farm animal welfare. British Food Journal, Vol. 104, 287-299

Hill, H. and Lynchehaun, F. (2002). Organic milk: attitudes and consumption pattern. British Food Journal, Vol. 104 (7), 526-542

Hutchins, R.K. and Greenhalgh, L.A. (1995). Organic confusion: sustaining competitive advantage. Nutrition \& Food Science Journal, Vol. 95 (6), 11-14

Kotler, P, (2003). Manajemen pemasaran sudut pandang Asia $\left(3^{\text {rd }}\right.$ ed.). New Jersey: Pearson Education, Inc.

Kotler, Bowen, dan Makens (1999). Consumer behaviour $\left(5^{\text {th }}\right.$ ed.). USA: Prentice Hall International, Inc.

Lea, E. and Wersley, T. (2005). Australians organic food beliefs, demographics, and values. British Food Journal, Vol. 11, 855-869

Lidyawatie, S. (1998). Perilaku Konsumen: Aplikasi dalam bisnis dan pemasaran, Jakarta: PT. Gramedia Pustaka Utama

Magnusson, M.K., Arvola, A., Koivisto Hursti, U.K., Aberg, L. and Sjoden, P.O. (2001). Attitudes towards organic food among Swedish consumers. British Food Journal, Vol. 103 (3), 209-226 
O’Donovan, P. and McCarthy, M. (2002). Irish consumer preference for organic meat. British Food Journal, Vol. 103 (3), 353-370.

Pearson, D. (2001). How to increase organic food sales: results from research based on market segmentation and product attributes. Agribusiness Review, Vol. 9 (8), 265-287.

Pranasari, M.E. (2007, Mei 10), Perdagangan produk pertanian organik. Kompas Cyber Media Retrieved November 14, 2008, from http://ww2. kompas.com/kompas-cetak/0411/08/ilpeng/137 0325.htm.

Ririn, S. (2008, November 3), Investasi kesehatan dengan produk organik. Republika Newsroom. Retrieved November 14, 2008, from http:// republika.co.id/berita/11477/Investasi Kesehatan dengan Produk Organik.

Ryan, W. (2008, November 22), Makanan organik kian mudah didapat. Kompas Cyber Media. Retrieved June 12, 2009, from http://www. kompas.com/kompascetak/2211/08/ilpeng/142 3045.htm.

Schiffman, L.G., and Kanuk, L.L. (1997). Consumer behavior $\left(6^{\text {th }}\right.$ ed.). USA: Prentice Hall International, Inc.
Steven, R., (2007, Maret 26), Why healthy lunch. Retrieved February 28, 2009, from http://www. healthylunchforyou.com.

Sugeng, H., (2007, Februari 23), Indonesia berpotensi jadi produsen tanaman organik dunia. Antara News. Retrieved February 28, 2009, from http://www.antara.co.id/print/?i=1190369888

Swastha, W. dan Irawan, F., (2001). Manajemen Pemasaran. Yogyakarta: Penerbit Andi .

Wandel, M. and Bugge, A. (1996). Environmental concern in consumer evaluation of food quality. Food Quality and Preference, Vol. 8 (1), 19-26

Wexley, E.D. dan Yuki, K. (1992). Marketing Strategy. USA: Prentice Hall International, Inc.

Widiastuti, S., (2004, April 23). Go organik 2010. Berita Pertanian Organik. Retrieved February 28, 2009, from http://www.go-organik2010/ beritapertanian/91887/organic.

Wilkie, P., (1994). Customer Buying Behaviour ( $3^{\text {rd }}$ ed.). USA: Prentice Hall International, Inc.

Zeithaml, Valerie, A.,et al., (1996). The behavioral consequences of service quality. Journal of Marketing, Vol. 60, 31-46. 